\title{
THE ILLINOIS CONSTITUTION AND THE COURTS
}

\author{
SAMUEL W. WITWER, JR.*
}

\begin{abstract}
$A^{\text {II }}$
too often those who advocate amendment and revision of the Illinois Constitution of 1870 rest their case chiefly on the need to revise the Revenue Article and the desirability of securing a legislative reapportionment which will afford the people of the state fair representation in the General Assembly. Unquestionably, these are objectives of great importance. Nevertheless, it is unfortunate that the emphasis which has been placed on these matters has tended to divert attention from the defects inherent in other articles of the constitution, affecting no less directly the public interest and equally needful of revision. A notable example is Article VI of the Illinois Constitution under which is carried on the important work of administering the state's justice. It is the purpose of this paper to show that in a number of respects the efficient administration of justice in Illinois is being seriously hampered by the provisions of the state constitution and that real improvement in the organization, structure, and manning of the courts must await substantial revision of the Judicial Article.

Consideration of the problem would seem timely for it will shortly be one hundred years since the constitutional groundwork was laid for the judicial system now prevailing in Illinois. A comparison of the provisions of the judicial articles of the three constitutions adopted since Illinois attained statehood, discloses that it was upon the adoption of the Constitution of $\mathrm{I} 848$, not the present constitution, that Illinois first chose the methods of judicial selection and tenure and erected much of the court machinery, utilized today in the administration of justice. ${ }^{x}$ For example, the method of popular election of judges was first adopted in the state in 1848 and that method of selection has since prevailed. ${ }^{2}$ The substitution of rela-

* Member of the Illinois Bar, Chairman of the Committee on Constitutional Convention of the Chicago Bar Association.

The author acknowledges with appreciation the valuable assistance given him by Professor Kenneth C. Sears of the University of Chicago Law School, in the course of preparing this article.

I The Constitution of $18 \mathrm{r} 8$ vested the state's judicial power in a Supreme Court and "such inferior courts as the General Assembly shall from time to time ordain." It provided for election of judges by the General Assembly and for their tenure during good behavior. Ill. Const. 1818, Art. 4 , $\$ \S 1,4$.

* Prior to its abolition in I905, the office of the justice of the peace in the city of Chicago was appointive. Ill. Const. 1870 , Art. $6, \S 28$. Judges of the Court of Claims, which is essentially an administrative agency, hold office by appointment of the governor.
\end{abstract}


tively short terms of office, in place of tenure during good behavior, as provided in the organic law of 1818 , was likewise an innovation of the state's second constitution. Today most of the judges of Illinois hold office for precisely the same terms as were established for their predecessors of a century ago. ${ }^{3}$ Likewise, with respect to the structure of the judiciary, the resemblance is close. Aside from providing intermediate appellate courts, additional courts for the County of Cook, and Probate Courts in more populous counties, the Constitution of I8jo vested the judicial power of the state in substantially the same courts to which it was entrusted by the framers of the Constitution of 1848.4

Under these circumstances, it might be assumed that the Judicial Article of the present constitution has undergone amendment from time to time to meet the impact of the great economic, social, and political changes which have occurred since 1870 . However, that has not been the case. In all, nineteen amendments have been submitted to the people and only seven have been adopted. 5 Aside from a provision of the Chicago Charter Amendment abolishing justices of the peace in the City of Chicago, none related to the judiciary. The lack of effort to amend the Judicial Article is not to be explained by any general satisfaction with the prevailing judicial system, but rather by the rigidity inherent in the amending process itself, ${ }^{6}$ and a belief held by advocates of reform that the deliberative method of constitutional convention is better suited to the solution of the state's judicial problems. ${ }^{7}$ It is true that the proposed constitution, which was defeated in the referendum of 1922 , presented an opportunity to reorganize

3 Under the Constitution of 1848 , judges of the Supreme, Circuit, and County Courts held office for terms of nine, six, and four years, respectively. Ill. Const. 1848, Art. $5, \$ 83,7$, I7; cf. similar provisions of Ill. Const. $x 870$, Art. $6, \$ \S 6,12,20,23$.

4 The Constitution of 1848 vested the judicial power of the state "in one supreme court, in circuit courts, in county courts, and justices of the peace; provided that inferior local courts of civil and criminal jurisdiction may be established by the General Assembly in the cities of the state. ...." Ill. Const. I848, Art. 5, § I; cf. Ill. Const. I870, Art. 6, § I.

$s$ The amendments submitted were the following: Drainage and Ditching (1878), adopted; County Officers (1880), adopted; Veto of Appropriation Items (I884), adopted; Anti-Contract Convict Labor (I886), adopted; World's Fair Bonds (I890), adopted; Gateway Amendment (1892), not adopted; Labor (I894), not adopted; Gateway Amendment (I896), not adopted; Chicago Charter (1904), adopted; Deep Waterway Bonds (rg08), adopted; Revenue Amendment (I9I6), not adopted; Gateway Amendment (1924), not adopted; Revenue Amendment (1926), not adopted; Revenue Amendment (1930), not adopted; Gateway Amendment (I932), not adopted; Banking (I938), not adopted; To Remove Sales Tax from Food (r942), not adopted; County Officers (I944), not adopted; and Gateway Amendment (r946), not adopted.

${ }^{6}$ Sears and Laughlin, A Study in Constitutional Rigidity, to Univ. Chi. L. Rev. I42 (1943) and II Univ. Chi. L. Rev. 374 (I944).

7 See statement of the Chicago Bar Association, entitled A Constitutional Convention for Illinois (June, 1947). 
the state's judiciary, but the only choice then afforded the people was acceptance or rejection of the new constitution in its entirety. ${ }^{8}$

In short, the judicial business of the state is now conducted under constitutional provisions unchanged since $I 870$ and in substantial accordance with the pattern formulated to meet the needs of citizens who lived a century ago and in a time far different from the present. ${ }^{9}$ This background naturally prompts inquiry concerning the adequacy of the state's judicial machinery in meeting present-day needs.

It is a truism that the quality of justice can be no higher than the quality of the men who administer it. Hence, the first prerequisite of an efficient and respected judicial system must be the adoption of principles of selection and tenure designed to bring to the bench men of integrity, independence, wisdom, and learning in the law. All agree that these are the attributes of the good judge, but difference of opinion exists as to the means of selecting and keeping such men on the bench.

When in 1848 Illinois commenced choosing its judges by popular election for relatively short terms, the state was following the trend which swept the country during the period from 1830 to $185^{\circ} .^{\text {ro }}$ The political philosophy then prevailing was that government could be better and more efficiently administered if power were vested only sparingly in public officers. The belief was widespread that decisions of the people registered at the polls would somehow express wisdom and secure a correct result. This theory was applied to the major public offices, including the judiciary. It was the view that by substituting the elective and fixed tenure principle, in place of appointment of judges to hold office during good behavior, the courts would become more responsive to the popular will and justice would be administered more efficiently. To a considerable extent these nineteenth-century notions of theoretical democracy survive today and

\footnotetext{
${ }^{8}$ It is believed that one of the principal reasons for the failure of the proposed Constitution of 1922 was the submission of the document as a unit rather than by articles or sections, the method followed in 1870 . See Dodd, Illinios Rejects a New Constitution, 7 Minn. L. Rev. 177 (1923); Davis, Defects and Causes of Defeat of the Proposed Constitution of 1922, 26 Chi. Bar Ass'n Rec. 276 (r945).

It is not suggested that in this respect the Illinois situation is unique. The Judicial Article of the Massachusetts Constitution of 1780 remains unchanged and all judges are appointed by the Governor with the approval of the Executive Council, with tenure during good behavior. Mass. Const. I780, c. 2, $\S$ I Art. 9; c. 3, Art. I3. The provisions of the present New Jersey Constitution relating to appointment and tenure of judges do not differ materially from those contained in the Constitution of 1776 . N.J. Const. 1844 , Art. $6, \S 6$ (I); cf. N.J. Const. I776, § I2. [Ed. Note. New Jersey voters approved a new constitution on Nov. 4, 1947.]

so Haynes, Selection and Tenure of Judges 80-r3o (1945).
} 
are advanced by those who wish to preserve the elective system. However, it must be recognized that the present-day situation differs greatly from that of a hundred years ago.

When the movement for an elective judiciary swept the country, the population of Illinois, like other states, was largely rural. In 1848 the population of Cook County was less than 350,000 , out of a total of $2,500,000$ people in the entire state. ${ }^{\text {II }}$ Then, as in 1870 when the present constitution was adopted, the economy of the state was agricultural, communities were small, and the problems of urbanism, including that of spoils politics, were unforeseen. Under those favorable conditions the innovation worked well for a time..$^{\mathrm{x}}$ Even today the elective system occasions little complaint in the downstate rural communities of Illinois. ${ }^{13}$ In those communities, aspirants for judicial office are known to their neighbors, the salaries of judges compare favorably with the restricted earnings of good lawyers in small county seats, and, generally speaking, the political organizations have neither been strong enough to deprive nor inclined to deprive the voters of a real basis for selection.

Since the adoption of the present constitution, revolutionary changes have taken place.in the manner of life of the people of the state. Industrialism replaced agriculture as the basis of the state's economy and was accompanied by a rising tide of urbanism. The period witnessed the growth of Chicago as the nation's second city and the growth of other important cities in the state. In Chicago, particularly, the change was accompanied by most of the evils of spoils politics as practiced in metropolitan areas. It has been said that these phenomenal changes alone have accounted for most of the problems which now confront the state, judicial and otherwise. ${ }^{\mathrm{I}}$

The method of popular election of judges has produced its most baleful results in Cook County, where for many years the electorate has had little voice in the selection of judges. Actually the system there in operation has proven more appointive than elective in nature, and generally the judges are chosen by the party bosses, often without regard to their records, experience, age, or capacity. Not without reason, the usual judicial election in Cook County has been characterized as a farce. ${ }^{15}$ In all elections

${ }_{12}$ The Sixteenth Census of the United States, 1940, shows that the population of Cook County was $4,630,342$, of which Chicago had $3,396,808$. The population of the state was $7,897,24$ I.

12 Pound, Criminal Justice in Cleveland 599 (The Cleveland Foundation, I922).

${ }^{3}$ Sears, Constitutional Revision and Party Circle Bills, $x_{4}$ Univ. Chi. L. Rev. 200 (I947).

${ }_{14}$ Report of Committee on Organic Law and Legislation, I3 Illinois Postwar Planning Commission (Jan. I945).

ss Sears, op. cit. supra note $\mathrm{I}_{3}$, at 206. 
of Superior and Circuit Court judges conducted since 1927 , one or both major parties have presented "coalition" tickets. In a number of elections held since that year, the two parties have presented a single unopposed judicial slate, thus giving the voters no choice whatever. The selection of judges of the County, Probate, and Municipal Courts, through the machinery of primary and general elections, has produced equally unsatisfactory results. Nominations are dictated by the party bosses and in most instances the results of the general election are a foregone conclusion. The plain fact is that in Cook County judges are selected and kept in office by and at the sole pleasure of the party organizations. Something of a tradition has developed in the county to re-elect automatically the sitting judges, a practice few would condemn if the incumbents always proved to be qualified. However, the party bosses have come to enjoy such absolute power in their roles as "judge-makers" that they pay scant attention to the records and qualifications of their appointees and not infrequently they openly flaunt the opinions and recommendations of the bar.

A practical demonstration of how the system works in Cook County has just taken place. In November, twenty-one candidates for judicial office on the "coalition" slate were elected. Prior to the recent conventions it appeared that the Democratic and Republican leaders would select a "coalition" slate which would include the names of a majority of twenty sitting judges, despite protests of the bar association that ten of the number were not qualified to hold judicial office for another term. However, the protests of the bar, based in a large measure upon a poll taken of its members, denunciations by all the major metropolitan newspapers, ${ }^{{ }^{6}}$ and the appearance of an independent slate of judges apparently have had some effect this year in that the party leaders have replaced five of the incumbents. This dubious success has been summed up thus: "All in all, the coalition slate, while perhaps a little better than was expected .... is still a good deal less than satisfactory. The result underlines once again the generally undesirable method of selecting judges in this community."'17

It is noteworthy that in the same bar poll several of the sitting judges of the Superior Court received ratings of considerable excellence. ${ }^{8}$ Considering the political influences with which a judge of Cook County must contend in the process of holding and being returned to office, those ratings are a tribute of the highest order to the integrity, independence, and

${ }^{16}$ Editorial, The Bar's Ratings, Chicago Daily News (Aug. r, r947); Editorial, The Judicial Slate, Chicago Tribune (Aug. 2, 1947).

${ }^{27}$ Editorial, The Judicial Slațe, Chicago Tribune (Aug. 27, 1947).

${ }^{18}$ In the recent "bar primary" of the Chicago Bar Association, six of the sitting judges of the Superior Court of Cook County received ratings of $9 \circ$ per cent or better. 
all-around fitness of the judges who received them. Unfortunately, such judges are too few in number and it is fair to observe that when Cook County obtains good judges it does so in spite of the nominal elective system and not as a result of the methods of judicial selection now utilized.

The present activity of the organized bar of Chicago is by no means a recent development; in fact, almost continuously since the Chicago Bar Association was founded in 1874 , it has sought to bring about the election of good judges in Cook County. The basic feature of the Association's effort has been the "Bar Primary," which is merely a method of registering the opinion of its members concerning the fitness and merit of individual candidates. In most instances results of the "primary" afford the basis of the Association's recommendations to the public. The Association has also carried on a long-time program challenging the methods of selection and tenure in their more fundamental aspects. It has sought constitutional and legislative changes designed to bring better men to the bench and to keep them there.

The story of the Association's struggle for an improved judiciary is ably and fully recounted elsewhere. ${ }^{19}$ It is a record of an enormous outlay of time, effort, and money by generations of Chicago lawyers, marked by many defeats and rewarded by few successes. While important in showing how unrelenting a group of lawyers can be in demanding that justice be administered by qualified men, in the last analysis its real significance lies in demonstrating both the failure of the elective system in Chicago and the fact that nothing much can be done about the situation until the state's constitution is revised. In recognition of this fact the Chicago Bar Association in 1937 recommended fundamental changes in Article VI of the Constitution, pertaining to the selection and tenure of the Circuit, Superior, and Probate Court judges of Cook County, and in a report to its members ${ }^{20}$ said:

For many years the bar of Chicago have been satisfied that a change in the method of judicial selection is imperative. We believe that the judiciary should be and would like to be free from politics, from the dangers of being removed from office by the winds of party elections, from the necessity of contribution to political parties to secure nomination and election, from participation in political activities and the dangers of a refusal to participate, to say nothing of attempted political influences in the discharge of judicial duties.

These evils are recognized not only in Chicago but in all metropolitan areas, as evi-

I9 For an excellent account of the efforts of the Chicago Bar Association in improving methods of judicial selection and tenure, see Martin, The Role of the Bar in Electing the Bench in Chicago (Univ. of Chi. Press, I936).

${ }^{30}$ Report of Board of Managers, Chicago Bar Association entitled, A Plan for Júdicial Selection (Jan. 20, 1937). 
denced by the consideration now being given to the subject in nearly all large cities. They are recognized as evils peculiar to metropolitan communities. For this reason it has not been deemed advisable to change the system outside of Cook County. In the down state counties the persons selected are well known to the bax and to the people of their community. Here many judges are not known to the community until after long service on the bench. Some of the candidates are scarcely known to the bar. The method of their selection at present is more appointive than elective since the nominee is practically the appointee of the party committees. The election is usually made a mere formality by a coalition ticket. While a coalition ticket is bad, an election in which two parties present full slates often has equally baleful results. One political party or the other at times is so powerful that its candidates are elected and judges of the minority party who have had excellent records on the bench entitling them to reelection have been swept out of office by party landslides.

Our principal object is to improve the quality of judicial service. In order to do this, the method of initial selection must be improved; the judges must be given a longer and more certain tenure of office; the selecting power must be placed in the hands of those who can be held accountable for its abuse; ample safeguards must be provided against an arbitrary appointive power; the right of the people to remove a bad or incompetent judge must be retained.

The plan advanced by the bar association in 1937 was an attempt to retain the principle of popular control of the judiciary while eliminating the evils inherent in the elective system. It was a compromise between conflicting philosophies, the view on the one hand that all judges should be appointed by a responsible authority to hold office during good behavior, as in the federal judiciary, and the opposing view that in a democracy judges should be made responsive to popular will by requiring them to stand for election at frequent intervals. The bar association proposed that the names of the judges of the Circuit, Superior, and Probate Courts of Cook County, in office upon the plan becoming effective through constitutional amendment or revision, should be submitted to the electorate at the November biennial general elections following expiration of their respective terms, without opposition or party designation, upon the sole question whether such judges should be retained in office. If a majority voting on the question and constituting not less than 25 per cent of those voting in the general election voted against any judge, his office was to become vacant thirty days thereafter; otherwise, the judge was to remain in office for a term of ten years, at the expiration of which time his name was to be submitted again in the same manner. Under the proposal, vacancies in office were to be filled for initial four-year terms by appointment by the Governor from a list of eligible persons nominated by a Commission to be composed of five residents of Cook County. The Commissioners in turn were to be elected by majority vote of the judges of the Appellate Court 
for the First District, were to serve without eompensation and no more than three of them were to be members of the same political party. The plan advanced by the Chicago Bar Association made no provision for the County Court of Cook County because of the view that it is more an administrative office than a judicial one. Likewise, the plan did not extend to the Municipal Court of Chicago, which is a statutory court and subject to regulation by the legislature. The bar association drafted a bill designed to put in operation in the latter court methods of judicial selection similar to those described. ${ }^{2 x}$ Repeated attempts to enact such legislation under the joint sponsorship of the bar association, the Chicago Federation of Labor, and others, have failed ${ }^{22}$ despite unusual public interest and widespread support for the proposal. ${ }^{23}$ The establishment of the plan in the Circuit, Superior, and Probate Courts, of course, awaits amendment or revision of Article VI of the Illinois Constitution.

This system, whereby judges are permitted to "run on their records," was adopted in California in I934..$^{24}$ It has been in effect in Missouri since $1940,{ }^{25}$ where the results have met with public approval. Since the adoption of the plan in that state the people of Missouri have voted on the question whether the system should be retained and they voted affirmatively by a substantial majority. Several other states have similar proposals under consideration and the pendulum seems once again to be swinging, this time toward a compromise between the extremes of the appointive and elective methods of judicial selection and tenure..$^{26}$

${ }^{2 x}$ Ill. H.R. 61st Assemb. 748 (I939). The bar association originally proposed that the chief justice and associate judges of the Municipal Court of Chicago be appointed in the first instance by the judges of the Appellate Court for the First District. This proposal was discarded, primarily because of the opposition of the Chicago Federation of Labor to the appointive method of judicial selection. Instead, the bill provided for election of judges in the first instance upon a non-partisan ballot, thereafter the judges being required to "run on their records." See Report of Committee on Judicial Selection, Chicago Bar Association (Mar. 9, 1939).

$\approx$ Efforts to pass such legislation in recent sessions of the General Assembly have failed by narrow margins due to a partisan dispute over the question whether the thirty-seven Democratic judges now in office should be required to submit to the non-partisan election provided for the initial term of four years. The Democrats desired those in office to be given the benefit of the tenure provisions without submitting to those provisions relating to initial selection. The Republicans objected to "blanketing-in" the sitting judges.

${ }^{23}$ See the following editorials: For an Independent Bench, Chicago Sun (Apr. 30, 1943); A New Way to Elect Judges, Chicago Tribune (May 3, I943); Blind Lady Seeks Divorce, Chicago Daily News (Apr. 30, I943); and Protect the Courts, Chicago Daily Times (May 4, 1943).

24 Calif. Const., Art. 6, $\$ 26$ (Amended, 1934).

${ }_{25}$ Mo. Const., Art. 6, $\$ 3$ (Amended, I940).

${ }^{26}$ Martin, op. cit. supra note 18 , at $360 ;$ McCormick, Judicial Selection-Current Plans and Trends, 30 Ill. L. Rev. 446 (I935). 
Aside from the above-mentioned proposals many other suggestions have been made for improving methods of judicial selection and tenure in Illinois. Appointment of all judges by the Governor has been advocated as the best method of overcoming the evil influence of politics in the selection of judges, ${ }^{27}$ while under another proposal the bench would fill its own vacancies..$^{28}$ It has been suggested that the appointive power be vested in an elective chief justice of the Supreme Court ${ }^{29}$ whose appointees would hold office during good behavior or for terms of years longer than those now prescribed. A variation of this latter plan would require judges appointed by the chief justice to "run on their records" following short initial terms..$^{30}$ Many other suggestions have been made for improving the means of selecting Illinois judges. ${ }^{3 x}$ In fact, so much has been written by students of the problem that one is prompted to ask whether there has not been a misapplication of effort, a case of putting the cart before the horse. Obviously, the best reasoned plans for improving judicial selection in Illinois can be little more than futile academic exercises until Article VI of the Illinois Constitution is thoroughly revised. What is needed is a frontal attack on the problem, a concerted and continuing effort to the end that Illinois may have its constitutional convention at the earliest date possible.

Preoccupation with the problems of the Cook County judiciary should not be permitted to obscure the need for improved methods of selecting the state's Supreme Court. Members of that court are elected from seven judicial districts which are substantially as established in 1870 . Then the districts were of approximately equal population and the framers of the present constitution contemplated redistricting by the legislature "upon the rule of equality of population." $3^{2}$ Today more than half of the people of the state reside in the Seventh District, which consists of Cook County and the outlying counties of Will, Kankakee, Lake, and DuPage. In this district originate nearly 60 per cent of the cases which regularly come before the Supreme Court. ${ }^{33}$ Notwithstanding these facts, under the present

${ }^{27}$ Ill. Bar Ass'n Proc. (Ig09); 2I Ill. Bar J. 7 (1933).

${ }^{28}$ Rosenbaum, Election of Judges, or Selection, 9 Ill. L. Rev. 489 (IgI5).

${ }^{29}$ Kales, Methods of Selecting Judges, 85 Cent. L.J. 425 (I917); Hinton, The Selection of Judges, 2 I Ill. L. Rev. 6I2 (I927).

${ }^{30}$ Martin, op. cit. supra note 18 , at 353 . (x934).

${ }^{3 x}$ McCormick, A Proposed Reorganization of the Illinois Judiciary, 29 Ill. L. Rev. 3 I

32 Ill. Const., Art. 6, \& 5.

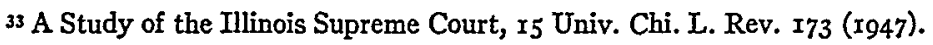


constitution the residents of the Seventh District elect but one member of the court, while the rest of the state elects six judges. The inequality exists in a lesser scale in other districts. For example, the Third District now has a population almost twice that of either the Fourth or Fifth Districts. ${ }^{34}$ Even if the legislature, contrary to past experience, were to provide a judicial reapportionment, the Illinois Constitution would preclude giving Cook County the right to elect more than a single member of the court. The constitutional requirement that "the districts shall be of contiguous counties" prevents creation of a Supreme Court district consisting of less than two adjoining counties, not to mention a district smaller in area than a single county.

- Little can be said for dividing the state into separate districts for electing the Supreme Court. The divisions are arbitrary and the method bears no relation whatever to accomplishing the selection of the ablest men available for the state's highest bench. Certainly, it cannot be justified by any argument that "sectional" interest or bias should find representation in the determinations of the court, for any such notion would be repugnant to fundamental concepts of justice. Even in the Constitution of 1848 it was made optional whether the judges of the court would be elected in separate districts or on a statewide basis. ${ }^{35}$ Among the thirty-five other states, exclusive of Illinois, in which the judges of the courts of last resort are popularly elected, ${ }^{36}$ only six provide by constitution for the election of the judges from separate judicial districts. ${ }^{37}$ The sensible course would be to abolish the elective system with its arbitrary, political districts and to provide for the appointment of the justices of the Supreme Court as is done with satisfactory results in eight other states. ${ }^{38}$ Pending such change the present grossly unequal districts should be abolished.

34 In I940 the population of the Third District was 734,915 and the populations of the Fourth and Fifth Districts were 422,663 and 449,694 , respectively. See A Constitutional Convention for Illinois (League of Women Voters of Illinois, 1947).

35 IIl. Const. 1848, Art. $5, \S 3$.

${ }^{36}$ Alabama, Arizona, Arkansas, Colorado, Florida, Georgia, Idaho, Indiana, Iowa, Kansas, Kentucky, Louisiana, Maryland, Michigan, Minnesota, Mississippi, Montana, Nebraska, Nevada, New Mexico, New York, North Carolina, North Dakota, Ohio, Oklahoma, Oregon, Pennsylvania, South Dakota, Tennessee, Texas, Utah, Washington, West Virginia, Wisconsin, and Wyoming.

37 The constitutions of Indiana, Oklahoma, and South Dakota provide for election of Supreme Court judges from separate districts by the electors of the state-at-large. In Nebraska the chief justice of the Supreme Court is elected by state-wide vote, while the associate justices are elected by the electors of the various districts as are the judges of the supreme courts of Kentucky and Maryland.

${ }^{38}$ Appointive systems are provided in the state constitutions of California, Connecticut, Delaware, Maine, Massachusetts, Missouri, New Hampshire, and New Jersey. The constitutions of Rhode Island, South Carolina, Vermont, and Virginia, provide for the election of the judges of the highest courts by joint action of both houses of the state legislatures. 
At this juncture the important thing is not so much agreement upon the details of the best possible method of judicial selection but rather removal of the constitutional blocks which now preclude any improvement whatever. When the Judicial Article is revised no single method of selection should be rigidly prescribed for all the courts of the state, for that is a vice of the present constitution. Instead, the people of each county should be afforded a choice, by referendum, between one of several methods..$^{39}$ As for Cook County, any change would be an improvement over the present system. So long as the residents of Cook County have no voice in the selection of their judges, it would be far better to strip the party bosses of their power to designate the judges and to vest appointive power in responsible hands. If the elective short-term method continues to prove satisfactory in the rural counties, then, of course, no change is required, but that fact should not prevent more than half the residents of the state who live in large urban centers from adopting a different method, designed to overcome the evils of big-city, partisan politics. At present the important thing is to recognize that neither the plan of the Chicago Bar Association nor any other comprehensive program for improved judicial selection may be established in the absence of a general revision of the Judicial Article of the Illinois Constitution.

\section{II}

There is a regrettable disposition to blame judges for all the defects in the administration of justice when in fact many of its shortcomings are attributable to the defective organization-or lack of organization-provided by the Illinois Constitution of I870. Most criticism of the courts is directed to the administrative side of the judicial function, to the failure of the courts to do their work in an efficient and businesslike manner. In the main, the criticism is valid. The judicial system in Illinois is not efficient, many courts are unable to accommodate themselves to varying pressures in volume and kind of business, and justice is neither speedy nor inexpensive..$^{\circ}$ These conditions are the inevitable by-products of a complex and extensive judicial establishment, consisting of a large number of separate and independent units operating without semblance of co-ordination or over-all superintendence.

The state has altogether too great a variety of courts. Outside of Cook County, the state is divided into seventeen Circuit Court districts, each of

${ }^{39}$ The rejected Constitution of 3922 adopted the elective system, but provided that by referendum the residents of Cook County might establish a system whereby the judges of a single Circuit Court would be appointed in the first instance and "run on their records" at intervals of six years. For text, see Blue Book of the State of Illinois 293-3I4 (I923-24).

$4^{\circ}$ See Statement, Chicago Bar Association, op. cit. supra note 7 , at 6. 
which has three circuit judges. These are the major trial courts of general jurisdiction. In each of the ror counties, there is a County Court and counties having a population of 70,000 or more residents may have a Probate Court presided over by a separate probate judge. Most of the counties which meet this population requirement have Probate Courts. Twentyseven downstate cities have city or municipal courts which are statutory courts. In addition the townships have their justices of the peace.

The organization of the courts in Cook County is even more cumbersome, with a large number of courts bearing peculiar and arbitrary relations to each other. The courts of general jurisdiction are the Circuit and Superior Courts, manned by twenty and twenty-eight judges, respectively. These are entirely distinct courts which are identical in every power except that the Circuit Court of Cook County determines the number of deputies and assistants which may be employed in the offices of the county treasurer, sheriff, coroner, and other "fee offices," a non-judicial function..$^{4 x}$ These courts do not themselves possess criminal jurisdiction, as do the Circuit Courts downstate, but furnish the judges of the Criminal Court of Cook County for the trial of felony cases. They also furnish a judge for the Juvenile Court, which is a branch of the Circuit Court of Cook County. The Municipal Court of Chicago with a chief justice and thirty-six associate judges, possesses virtually complete trial jurisdiction except as to chancery and felony cases. In addition, Cook County has its County Court, Probate Court, the Municipal Court of Evanston, the City Courts of Calumet City and Chicago Heights, and justices of the peace in the outlying townships.

Fortunately, the appellate court structure is less involved. The Supreme Court, with its seven justices, is the court of final appeal and has original jurisdiction only in cases relating to revenue, mandamus, and habeas corpus..$^{42}$ The intermediate appellate courts are in four districts. Cook County comprises the First District, which is divided into three divisions. The remaining Ior counties of the state are divided into three contiguous areas constituting the remaining three appellate court districts. Three Circuit Court judges, appointed by the Supreme Court, constitute the judicial personnel of each district, except that in the Appellate Court for the First District nine judges are appointed from the Circuit and Superior Courts of Cook County. In brief, this is the court structure of the state. ${ }^{43}$

In providing for this extensive court system the framers of the Con4 Ill. Const., Art. ro, § 9. $\quad$ Ill. Const., Art. 6, $\S 2$.

43 See Blue Book of the State of Illinois $129-33$ ( $1945-46)$. 
stitution of 1870 failed to afford any means of co-ordinating the work of these many courts or administering them as part of a state-wide system. ${ }^{44}$ Consequently, the courts operate as separate and independent units, administratively sufficient unto themselves and without any general superintendence. This is true from the top to the bottom of the state judiciary. The Supreme Court appoints the judges of the appellate court and stops short at that point. It does not direct or superintend the administrative conduct of that court's business, notwithstanding that the appellate courts were created as assistants to the Supreme Court in the handling of appeal matters. In turn, the appellate courts exercise no supervision over the administration of justice in the trial courts. Under the constitution the basic function of the higher courts, in relation to those at the trial level, is the review of their decisions, and administratively they are complete strangers. While some little progress has been made in Cook County toward integrating the work of the Superior and Circuit Courts, generally speaking, there is no co-ordination in the work of the trial courts of the state.

Students of the problem are fairly unanimous in the opinion that unification of the courts under a single directing head is as essential to the successful administration of justice in Illinois as it is essential to the successful administration of any large business enterprise. The problem of administering justice is not basically different from that of business and industrial administration. The courts and judges constitute the state's primary judicial resources. The administration of justice ought to be considered a unified problem of the entire state, just as is other business of the state government. The objective should be to make the best possible use of these resources for getting the job done. Litigation varies both in volume and complexity at different times and places throughout the state, and it is possible to devise a system of judicial administration which will permit courts to adjust themselves to variations in the pressures of volume and kind of business. The difficulty is that the present constitution makes such a rigid disposition of the state's judicial resources that it is not possible to conduct the legal business of Mllinois with the flexibility and efficiency which would be demanded of a successful business enterprise. While the matter of administering justice should be considered as a unified problem of the entire state, Chicago conditions differ so greatly from those elsewhere in the

44 The constitutional requirement that all judges of inferior courts shall file written reports with the Supreme Court annually, which in turn shall report to the governor in writing "such defects and omissions in the Constitution and laws as they may find to exist," is to a considerable extent a dead letter. It appears to have accomplished little. Ill. Const., Art. $6, \S 3$ I. 
state as to require two court organization plans, one for Cook County and the other for the remaining counties.

Chicago has grown far beyond the court plan which seemed sufficient in I870, and the piecemeal reforms attempted since have failed to meet the needs. No one would consciously create a maze of separate courts such as has grown up in Cook County in an effort to "get along" under the state's inelastic and rigid constitution. Because the need for improvement there is so emphatic, it has been said that even a system of co-ordinated courts in Cook County alone would be a worthy accomplishment. ${ }^{45}$ Fortunately, much valuable groundwork has been done towand solution of the problem. The American Judicature Society, founded in Chicago in I9r3, led the way in directing attention to the need for a single, well-administered trial court in the larger cities, ${ }^{46}$ and for many years students of the problem have contemplated the ultimate merger of all the Cook County tribunals into a single, consolidated court. ${ }^{47}$

Such a unified court was provided in the rejected Constitution of I922, $^{2}$ which proposed doing away with the seven existing trial courts of Cook County and dividing the corps of judges between a Civil Division and a Criminal Division of a single court to be known as the Circuit Court. Each division was to be supervised by a chief justice designated by the Supreme Court and subject to removal by it. The I 922 draft provided for a single chief clerk of the court and the abolition of the clerks' offices of the Superior, Criminal, Probate, and County Courts of Cook County and the Municipal Court of Chicago. The Supreme Court was given the authority to empower the Circuit Court to appoint assistant judges, and to prescribe their powers and duties. It also recognized the fact that the appellate courts are assistants to the Supreme Court, and therefore their work should be supervised by the Supreme Court, and it gave to the Supreme Court power to appoint appellate court judges from the bench and bar generally, power to remove them and to increase their number as the volume of work required. This was a necessary provision to co-ordinate the functions of the appellate court and the single trial court of Cook County. The advantages offered by the proposal were many. It placed the full responsibility for efficiency and good results in the courts themselves, as it should be, and afforded the judges a flexible organizational structure capable of producing such results. It made possible the prompt assignment and shifting of judges within the court so as to permit the court to accommo-

45 Sears, op. cit. supra note ${ }_{3}$, at 34 .

${ }^{46}$ See Model Judicial Code, 3 J. Am. Jud. Soc. I32-4I (I920).

47 Martin, op. cit. supra note 18 , at 354. 
date itself to varying pressures of business. Under the proposal, work could be divided along functional lines and the judges were afforded an opportunity to become expert in particular areas of judicial business according to their previous training and individual capacities. Finally, the ultimate responsibility for the prompt and satisfactory disposition of all litigation in the county was placed squarely upon the shoulders of the Supreme Court without having that responsibility divided, as it now is, between the various independent courts and the legislature..$^{48} \mathrm{It}$ is regrettable that this meritorious plan was not adopted for it promised an end to the chaotic and inefficient judicial administration which has so long plagued Cook County. The problems are as acute today as ever and call for renewed study and consideration.

A plan for the remainder of the state should have the same objectives, though conditions of administration are substantially different from those in Cook County. Fortunately, downstate Illinois is not burdened with such a jumble of courts as has grown up in Chicago. The present County Court in each county should be retained as a court of limited jurisdiction, for in such essentially local matters as the probate of estates, assessment and collection of taxes, and in small civil and criminal matters, the county is a natural unit for administration. However, it would be well to abolish the existing Probate Courts and return all probate jurisdiction to the County Court where it originally reposed. The elimination of twenty-seven city and municipal courts outside of Cook County and transfer of their business to the County Court would provide more efficient administration. Two or more judges could be provided for each County Court if the volume of business so required. ${ }^{49}$ However, the problem outside of Cook County is not basically one of consolidating tribunals.

In the downstate counties there is about as much judicial business in proportion to population as elsewhere, but it is scattered over wide territories, and distance is the chief obstacle to the efficient administration of justice. The problem is to have judges available when and where judicial business awaits disposition. With the great improvements which have taken place in transportation and communication this need not be the source of difficulty it once was. What is required is co-ordination of the work of all trial courts under the administrative supervision of a single officer or body

\footnotetext{
${ }_{48}^{8}$ For text of provisions of proposed Constitution of 1922 , pertaining to Cook County court organization, see Blue Book of the State of Illinois, 293-3 I4 (1923-24); for comparison with present provisions, see The Proposed New Constitution for Illinois $45^{-9} 9$ (Chicago Bur. of Efficiency, I922).

49 The abolition of the Probate and City Courts was among the few changes proposed in the Constitution of rg22 relating to courts outside of Cook County.
} 
constantly advised concerning the ebb and flow of litigation throughout the state. To facilitate administration, the present seventeen circuits could be reduced in number or, as once advocated by committees of the Illinois State Bar Association and Chicago Bar Association, ${ }^{50}$ they might be consolidated into a single, state-wide Circuit Court which would operate in divisions under the superintendence of the Supreme Court and be manned by as many judges and assistants as necessary to meet the requirements of business. The present statute whereby judges may be interchanged from one circuit to another or between counties has accomplished little. In a number of instances the attraction of per diem allowances, in addition to regular pay, has resulted in downstate judges sitting for months at a time in Cook County courts with seeming disregard for the condition of court calendars at home. While the practice has relieved the pressure of judicial business in Cook County, consequent upon vacations, illnesses, and other absences of judges, it has resulted in well-justified resentment and complaint on the part of lawyers in downstate communities. The necessary co-ordination of the work of the trial courts outside of Cook County could be accomplished by means of an administrative officer as in the federal judiciary and in one state, ${ }^{5 x}$ or preferably by making the $\mathrm{Su}-$ preme Court responsible for the assignment of judges and the administration of justice throughout the state as a whole. A necessary feature of any such plan would be the gathering and publication of information and statistics concerning the work of all judges, for use in the day-to-day management of the state's judiciary.

Responsible judicial administration should include the power to discipline judges for misconduct in office. The process of removing judges for cause by a concurrent three-fourths vote of the members of each house of the legislature certainly has not fostered a high standard of conduct in the judicial office. It appears not to have been utilized since the adoption of the Constitution in I87o, and only once in the history of the state was an attempt made in the legislature to remove a judge from office by the impeachment process. ${ }^{32} \mathrm{~A}$ method of disciplining judges, free from the influence of partisan politics, should be provided. A logical solution would be to vest in the Supreme Court power to discipline judges of the lower courts, thereby giving that court authority and power commensurate with the great responsibilities it would have in the superintendence of the ad-

${ }^{50}$ See Joint Report of Committees of Ill. State Bar Ass'n and Chicago Bar Ass'n, A Judiciary Article for the New Constitution (I92I).

${ }^{\text {st W. Va. Code Ann. (Michie, I943) Chap. 5I, Art. x, } \$ \S ~ I 5-8 ~(A m e n d e d, ~ I 945) . ~}$

52 Martin, op. cit. supra note 18 , at 329. 
ministration of justice throughout the state. The Supreme Court should also be empowered to retire from office judges who become mentally, physically or otherwise incapable of performing their duties efficiently and properly. Fair retirement pensions and disability allowances should be provided for those judges retired through no fault of their own. Missouri has adopted constitutional provisions vesting retirement powers in a committee of judges,,$^{53}$ and a similar proposal was among the constitutional amendments submitted and approved by a vote of the people of New York this November. ${ }^{54}$

Any program for reorganizing the state's judiciary would be incomplete without providing major changes in the justice of the peace courts. These are the only courts which thousands of citizens encounter in their lifetimes, and, with the great increase in traffic violation cases, all segments of society are now observing the inefficient and frequently disgraceful operations of these tribunals. The result is that public confidence in the judicial system as a whole is being impaired. To a large extent the fault lies in the antiquated fee system which is provided by the Illinois Constitution. In civil cases it has long been the tendency of many justices to find for the plaintiffs who pay the fees, rather than in accordance with the law and facts. The fee system should be abolished and regular salaries provided as in other states. ${ }^{55}$ In addition, the justices of each county should be placed under the direct and continuous supervision of the County Judge or other court of record. The office of justice of the peace should be abolished wherever reasonable access may be had to other courts affording comparable remedies. By coupling these simple changes with improvement in the method of selection, the justice of the peace courts could be made useful and respected tribunals. Here again the road to any real improvement is blocked by the inelastic provisions of the constitution.

\section{III}

To the credit of the framers of the Constitution of 1870 , it should be observed that the system of appellate review has proved more satisfactory to the public and bar, alike, than has the trial court system. The Illinois Supreme Court and the four appellate courts of the state enjoy a respect which has not been accorded the nisi prius courts generally. Comparisons

53 Mo. Const., Art. 5, \& 2\%.

54 Brown, Proposed Amendments to N.Y. Constitution, 19 N.Y. State Bar Ass'n Bull. 44-8 (1947).

55 Missouri has made considerable headway in eliminating the evils of the fee-collecting justice of the peace system. Mo. Const. Art. 5, $\$ \S 18-21,24$. 
aside, it is clear, nevertheless, that the conditions under which the Illinois Supreme Court performs its work today prevent that Court from functioning as effectively as might be desired, and unless those conditions are rectified it will be futile to enlarge the Court's duties to include general superintendence of a unified system of courts, as previously suggested. On first impression it might seem that certain of these unfavorable conditions can be remedied by the Court itself, and others by legislative action. It is submitted, however, that in the last analysis they are the product of antiquated constitutional provisions which must first be revised if the Court is to be enabled to do its best work.

Foremost among the obstacles to flexible and efficient administration is the fact that the Court itself has little control over the number and type of cases in which it will afford final review. Instead, it is the litigants themselves, in certain favored classifications of cases where ultimate review by the Supreme Court is afforded as a matter of right, who make the determination as to whether or not the services of the Court will be utilized. To understand that curious result, it is necessary to consider briefly the constitutional and statutory provisions governing appellate jurisdiction. The Constitution provides for the creation of inferior appellate courts "to which such appeals and writs of error, as the general assembly may provide, may be prosecuted from circuit and other courts, and from which appeals and writs of error shall lie in all criminal cases and cases in which a franchise or freehold or the validity of a statute is involved, and in such other cases as may be provided by law." ${ }^{6}$ In all the cases specified in the italicized clauses, excepting criminal cases below the grade of felony, the legislature has provided for direct appeal to the Supreme Court, by-passing the intermediate appellate courts. ${ }^{57} \mathrm{In}$ addition, the legislature has provided for direct appeal to the Supreme Court in cases involving the construction of the Constitution, the validity of a municipal ordinance where the trial judge certifies his opinion that the public interest so requires, and in all cases relating to the revenue or in which the state is interested as a party or otherwise. ${ }^{58}$ In a number of special situations, either a direct appeal to the Supreme Court is afforded as a matter of right, or, as in workmen's compensation cases, the issuance of a writ of error to the trial court is left to the discretion of the Supreme Court. ${ }^{59}$ Aside from these provisions relating to direct review, the principal cases in which appeals may be taken to the Court via the route of the appellate courts are those involving I) mis-

$s^{6}$ Ill. Const., Art. 6, § II (italics added).

57 Ill. Rev. Stat. (I945) c. $37, \S 32$.

${ }^{8}$ Ill. Rev. Stat. (I945) c. I10, § I99. 59 Ill. Rev. Stat. (I945) c. $48, \S$ I56 (f) (2). 
demeanors, 2) cases in which a majority of the appellate court judges certify that questions of importance are involved, and 3) where the Supreme Court itself grants leave to appeal from final judgments of the appellate courts. ${ }^{60}$

For a long time it has been apparent to observers of the day-to-day work of the Supreme Court that the constitutionally guaranteed appeals in criminal cases and cases in which a franchise or a freehold or the validity of a statute are involved, consume the major part of the Court's time and preclude review by the Court of many other types of cases, equal, if not greater, in importance. This has seemed apparent from even a casual reading of the published opinions of that Court. Any recent volume of the Supreme Court Reports which may be examined will be found to contain opinions in a large number of criminal cases, a comparable number of opinions in cases involving wills, trusts, estates, and real property, reviewed because of the happenstance that freeholds were involved, and a goodly number of cases involving the validity of statutes and municipal ordinances. Notable for their comparative absence are the cases which account for most present-day litigation, namely, those involving torts, contracts, domestic relations, and business and commercial questions. The inability of lawyers to secure review beyond the appellate courts in these and other large and important areas of litigation has resulted in increasing dissatisfaction with the system of appellate review and demands that it be thoroughly overhauled. ${ }^{6 x}$ On the other hand, while somewhat tentatively asserting that the Illinois Supreme Court "could very likely be burdened with innumerable cases which are not today of sufficient merit to consume its attention," a student of that Court recently urged that specific proposals concerning improvement of the Court's working conditions be deferred until more is learned about the business of the Court through "careful analysis of statistical data showing the number of each type of case taken to the Court, the number of petitions denied, the disposal of each case and other similar data." ${ }^{\prime 2}$ If such detailed information were

${ }^{60}$ Ill. Rev. Stat. (I945) c. IIo, $\$$ I99. This section also provides that the Supreme Court may grant leave to appeal in cases where the Appellate Court reverses the trial court and remands for a new trial and "in which the party in whose favor the trial court's judgment or decree was rendered shall present to and file with the Appellate Court an affidavit stating that he will be unable on a future trial or hearing to adduce other or additional evidence .... and expressly waiving the right to a new trial. ...."

6x Hinshaw, Streamlined Justice, 35 Ill. Bar J. 278-82 (1947).

62 Lardner, Thoughts on the Supreme Court of Illinois, 42 Ill. L. Rev. 53, 69 (1947). In his article, Professor Lardner asserts at p. 70: "It may be clear that beneficial remedies to the advantage of the Court could be found with respect to the selection, organization and business of the Court. But the important fact is that considerably more study is necessary if the dis- 
needed to show the magnitude of the problem, then the excellent analysis of the business of the Court, published elsewhere in this issue of the $R e$ view, ${ }^{63}$ goes far toward supplying that need. Of particular bearing on the instant study are the statistics there set forth, showing that the constitutional appeals discussed above, alone, account for approximately one-half of all the cases reviewed by the Supreme Court, direct appeals permitted under both constitutional and statutory provisions accounting for 75 per cent of the cases reviewed. Under these conditions, it is not at all surprising to find that only in from to to 16 per cent of the cases reviewed does that Court have any choice, those being the cases in which the Court grants permission for review or petitions for writs of error. Only to this slight extent can it be said that the state's highest court has any voice in ordering and regulating its own work.

In its liberality in granting appeals to the Supreme Court as a matter of right in the classes of cases mentioned, the Illinois Constitution appears to go further than any other state constitution. Aside from the matter of appeals involving constitutional questions, the practice generally prevailing elsewhere is to leave to the legislature the determination of the types of cases and conditions under which appeals may lie to the court of last resort. A study of the organic laws of the other states discloses only five other state constitutions, exclusive of Illinois, which are interpreted by the writer as providing appeals as a matter of right in particular classes of cases. ${ }^{64}$

Pending a revision of the Judicial Article, the situation could be greatly improved if more of the cases in which ultimate review by the Court is provided by the Constitution were required to be taken to the appellate courts first, as is now done in appeals in misdemeanor cases. Clearly, it would be within the competence of the legislature to make such a change. The fact that only a small percentage of the misdemeanor cases now coming before the appellate courts are taken to the Supreme Court under the limited right of appeal suggests that a considerable number of the other types of cases now going directly to the Supreme Court could be finally

cussion of these matters is to be taken out of the realm of speculation, idle nonsense or unfounded idealism. Specific and significant proposals by which the Court, the bar, and the legislature could assist in bringing about an improvement of conditions should not be made without more extensive studies than have come to the attention of the author."

$6_{3}$ A Study of the Illinois Supreme Court, I5 Univ. Chi. I. Rev. I63 (I947).

${ }^{64}$ See Neb. Const., Art. 5 , § 2; N.Y. Const., Art. 6, § 7; Ohio Const., Art, 4, § 2; Okla. Const., Art. 7, $\$ 3$; Utah Const., Art. 8, $\$ 5$. The writer made no attempt to examine the many decisions of the state courts construing the constitutional provisions regarding appellate jurisdiction, although annotations were scanned to the extent available. 
disposed of in the intermediate review courts. Of course, the extent to which litigants would accept, as final, decisions of the appellate courts would be determined by the quality of the judicial service rendered by those courts. Such an enlargement of their duties would necessitate fundamental changes in the organization and administration of the appellate courts without which the over-all situation would become worse, not better. It is the feeling of many that the service rendered by the Appellate Court for the First District is superior in quality to that of the other three appellate courts. The principal explanation offered is that all of the judges of the First District are in continuous residence in Chicago, and devote full time to the performance of their review functions, thereby permitting that court greater opportunity for consultation, advisement, and the careful preparation of opinions. On the other hand, the judges sitting in the downstate appellate courts reside at widely separated points and are required to divide their time between the trial of cases in their respective circuits and the performance of their duties in the appellate courts. Obviously, those conditions impose hardships on the downstate appellate judges and militate against the most effective performance of their duties. A solution might well be the creation of a single downstate appellate court in place of the appellate courts of the three existing districts, to be manned by full-time judges who would reside at the place designated for the court to sit. ${ }^{65}$ Of course, this or any other plan for the reorganization of the appellate courts would necessitate the shifting of judges and administrative personnel, the return of some judges to full-time circuit court work, and, to a certain extent, a disturbance of the status quo in the downstate judiciary. It is submitted that therein lies the principal reason why a legislative reorganization is not likely to occur. Those judges of the state who desire to maintain the existing order have never wanted for effective influence in the General Assembly, and it is unlikely that any far-reaching reorganization of the appellate courts will occur through legislative action. Here, as in so many other fields of state government in which improvements are drastically needed, the remedies could be attained by legislation. If past experience is any criterion, it is unlikely that improvement will come from that quarter.

The Supreme Court should be granted full power to determine in what cases it will exercise appellate jurisdiction, in contrast to the present scheme of having its jurisdiction fixed in part by constitutional provisions and in part by legislative action. The work of the Court should be limited to cases of importance, such as those involving a construction of the Illi-

${ }_{65}$ The writer is indebted to Walter F. Dodd for this suggestion. 
nois Constitution, the construction or validity of statutes, and other matters of public interest, so that each case may be presented fully at the bar and receive thorough consideration by the entire Court. Run-of-the-mine appeals, ordinarily involving the sifting of evidence and the application of established rules of law, should be finally disposed of in the appellate courts. Some of the elements of such a plan were proposed in the constitution submitted in I922, which vested power in the Supreme Court to apportion appellate jurisdiction between itself and the appellate courts and to prescribe the final jurisdiction of those courts, subject to change by the General Assembly. Strangely enough, the framers of the Constitution of I922 proposed direct appeals to the Supreme Court, as a matter of right, in the same classes of cases as are mentioned in the present constitution, excepting, however, misdemeanors. While much may be said for guaranteeing ultimate review by the Supreme Court in felony cases, particularly those involving capital offenses, there can be no justification other than an historical one for favored treatment of cases involving franchises and freeholds. When the Judicial Article is finally revised, those trouble-making provisions should be eliminated once and for all.

In the process of revision, the original jurisdiction of the Court should be enlarged to permit exercise of such jurisdiction in cases of great public importance and, when necessary, to prevent a failure of justice. ${ }^{66}$ By general rules, the Court could determine, from time to time, the types of cases it would entertain, and it should not be necessary to define them with particularity in the constitution. At present the exercise of the Court's original jurisdiction in cases relating to the revenue, mandamus, and habeas corpus accounts for only a small percentage of the business of the Court. The Court cannot now act in matters of great public importance or to prevent failures of justice, except in cases involving those specific matters and forms of action. For example, if the Court's original jurisdiction were enlarged as suggested, the Court could, and probably would, regard the validity of most statutes as of great public importance, thereby permitting a speedy determination of the issue before injurious results to the public and individuals could follow if the statute were invalid.

Other adverse conditions preventing the Court from doing its best work may be mentioned briefly. For example, there is a growing feeling that appeals do not receive the thorough and deliberate consideration of all members of the Supreme Court; that a decision of the Court is basically the product of the reasoning of the judge to whom the case is assigned for

\footnotetext{
${ }^{66}$ Compare the proposed Illinois Constitution of 1922 , Art. $5, \$ 92$. For text, see Blue Book of the State of Illinois $293-3 \mathrm{I}_{4}\left(\mathrm{I}_{923}-24\right)$.
} 
preparation of the opinion. Accordingly, many lawyers look upon oral argument before the Court as a waste of time and of little influence in the ultimate result. Perhaps if the present membership of that Court is too limited to permit the Court to dispose of its business promptly, without denying opportunity for full consultation and deliberation by the justices, additional judges should be provided. Of course, any enlargement of the Court's personnel would necessitate constitutional change. The proposed Constitution of 1922 provided for a court of nine justices, the additional two judgeships being assigned to the Seventh Judicial District.

Doubtless, the Court would have greater opportunity for consultation and deliberation if its members were in Springfield continuously and did not return to their home districts during the vacation months following each of the five terms of court. Of course, no change in the Constitution would be required to enable the members of the Court to spend more time together, if they chose to do so. So long, however, as the judges of the Supreme Court are selected by popular election in separate judicial districts, they will naturally desire to maintain "home ties" and be loath to separate themselves from their constituents. Viewing the problem realistically, the solution lies in taking the Court out of local politics, at least, and providing that the Court shall be in continuous session for the transaction of business. Such a solution, of course, requires constitutional revision.

Another criticism of the manner in which the Supreme Court functions is that a great amount of its time is needlessly consumed in the preparation of full opinions in cases in which it approves both the decision and reasoning of the appellate courts. ${ }^{67}$ At one time the Court followed the practice of setting forth verbatim in its decision the opinion of the appellate court and expressly adopting it as its own opinion. It has been suggested that the present practice of writing full opinions in cases where both the reasoning and decision of the lower court are approved, may be due to a belief on the part of the Court that the bar will conclude that the Court has not given deliberate and full consideration to the appeal if it does not present its own exposition of the facts and law. If that be the true explanation, then it is high time that the Court be enabled to do its work as effectively as possible without the necessity of being concerned with consideration of such ill-founded complaints.

The foregoing is not intended as an exhaustive recital of all the problems of appellate jurisdiction which await solution. It is believed, how-

${ }^{67}$ Dodd and Edmunds, Appellate Jurisdiction and Practice in the Courts of Illinois 1007-8 (1929); also Dodd, The Work of the Supreme Court of Illinois, 2I Ill. L. Rev. 207-23 (1926). 
ever, that the matters which have been considered demonstrate both the need for improving the conditions under which the Supreme Court performs its service and, also, that little improvement can be expected until the Judicial Article of the Illinois Constitution undergoes revision.

\section{IV}

If the root cause of the state's judicial ills is the organic law, then the question remains as to what may be done to secure the required constitutional revisions. In a state notorious for its almost prohibitively restrictive provisions governing constitutional revision and amendment that question alone presents problems of great difficulty. Consideration of the historical accident by which the Illinois Constitution became unresponsive to change, upon the enactment of the Official Ballot Law of $189 \mathrm{I}$, or discussion of the statutory measures which could be undertaken to make the Constitution again as susceptible to amendments and revision as was contemplated by its framers, are matters which are discussed elsewhere ${ }^{68}$ and are not within the scope of this article. However, several conclusions may properly be expressed here bearing on the problems of constitutional revision in relation to the foregoing discussion.

For one thing, it is imperative that the people of the state become aware of what is due them in terms of expertness, faithfulness, and efficiency in the judicial office. The inefficiencies and shortcomings discussed have prevailed so long that they have come to be looked upon as inherent and inescapable features of the legal system itself. Certainly, this false notion should be exploded. Viewed in the light of a proper concept of judicial administration, the proposals for improvement outlined should not be looked upon either as radical innovations or as products of an unfounded idealism. Many of the innovations suggested have proved successful in other jurisdictions and there is every reason to believe that they will work here. Those who express fear that such methods may not prove workable because of alleged peculiarities in social, economic, and political conditions prevailing in this state should, at least, assume the burden of pointing out the nature of those peculiar conditions. Certainly, were the subject of this discussion the improvement of a business or industrial enterprise, comparable proposals would not be viewed as too venturesome, but, instead, would be roundly applauded as practical and realistic. Should we have lesser objectives when what is sought to be attained is improvement in the administration of justice?

${ }^{68}$ See Sears, op. cit. supra note 13. 
It is equally important that the members of the bar throughout the state make common cause in attacking the problem, head on, at its source. The tremendous effort which has been made by generations of Chicago lawyers to secure the election of better-qualified judges and to raise the standards of judicial service in local courts dwarfs, by comparison, the limited and sporadic efforts of the bar to secure either a new state constitution or means of amending the present organic law. One can only speculate as to what might have been accomplished had the same concentrated effort been made, year in and year out, to achieve revision of the Judicial Article of the Constitution. Moreover, the bar has not been alone in failing to deal effectively with the problems at their root. Library shelves abound with writings concerning defects in the judicial system, but seldom is more than passing reference made to the source of the difficulties. It is submitted that greater results would be achieved if "first things" were considered first.

The choice between revising the Judicial Article by the method of constitutional convention, on the one hand, and the method of amendment initiated by the legislature, on the other, seems clear. The problems are so complex and their proper solution of such transcendent importance to the people of Illinois that no revision should be attempted without full opportunity for study and deliberation, in an atmosphere as free of political influence as possible. A convention of delegates chosen because of their qualifications to render just such a service would be far better suited for the task than would be the General Assembly, dominated as it is by partisan political forces and burdened with other duties. Whichever method of revision is finally chosen, the work of securing a new Judicial Article for the Illinois Constitution will be long and arduous and will demand the best thought and efforts of the bar, the bench, and other students of the problem. Considering the great importance of the task, that prospect should discourage no one; for, in the last analysis, there is no more fundamental or important function of government than the administration of justice. 